\title{
Pengaruh Endorsement oleh Beauty Vlogger terhadap Minat Beli Kosmetik
}

\author{
Fenny, Riris Loisa \\ fenny.915160138@stu.untar.ac.id,ririsl@fikom.untar.ac.id
}

Fakultas Ilmu Komunikasi Universitas Tarumanagara

\begin{abstract}
Increasing internet users is a huge market potential for business people to expand market share and to increase sales. This is because, the internet is one effective marketing communication tool for business people to increase sales of their products. The most appropriate means is through advertising promotion media. With Instagram companies can offer their products through beauty vloggers and endorsements to increase the interest of cosmetic products offered. This study aims to determine the effect of Endorsement in Beauty Vlogger on Interest in Buying Cosmetic Followers Instagram @ Storyofsand, using marketing communication theory with the conceptual foundation of beauty vlogger endorsement, buying interest. This study uses quantitative survey methods, this study uses 100 samples of @storyofsand followers by using data analysis of validity test, reliability test, simple regression analysis test, and Hypothesis Test through the application of SPSS 25.0 software. The results showed Ha was accepted, which means that there was a positive and significant influence of Endorsement in Beauty Vlogger on Interest in Purchasing Cosmetic Followers Instagram@Storyofsand and had an R square determination of 67.5\%, the rest were influenced by other factors outside the study.
\end{abstract}

Keywords: beauty vlogger, endorsement, purchase interest

\begin{abstract}
Abstrak
Peningkatan pengguna internet merupakan potensi pasar yang besar bagi para pelaku bisnis untuk memperluas pangsa pasar serta guna meningkatkan penjualan. Hal ini dikarenakan, internet merupakan salah satu sarana komunikasi pemasaran yang efektif bagi para pelaku bisnis untuk meningkatkan penjualan produknya. Sarana yang paling tepat adalah melalui media promosi iklan. Dengan instagram, perusahaan dapat menawarkan produknya melalui beauty vlogger dan endorsement guna meningkatkan minat produk kosmetik yang ditawarkan. Penelitian ini bertujuan untuk mengetahui pengaruh endorsement oleh beauty vlogger terhadap minat beli kosmetik follower Instagram @Storyofsand. Teori yang digunakan adalah komunikasi pemasaran dengan landasan konseptual beauty vlogger endorsement dan minat beli. Penelitian ini menggunakan pendekatan kuantitatif dengan metode survei, penelitian ini menggunakan100 sampel followers@storyofsand dengan menggunakan analisis data uji validitas, uji reliabilitas, uji analisis regresi sederhana, dan Uji Hipotesis melalui apikasi software SPSS 25.0. Hasil penelitian menunjukkan Ha diterima yang artinya terdapat pengaruh positif dan signifikan Endorsement dalam Beauty Vlogger terhadap Minat Beli Kosmetik Follower Instagram @Storyofsand serta memiliki pengaruh determinasi R square sebesar $67,5 \%$ yang sisanya dipengaruhi faktor lain diluar penelitian.
\end{abstract}

Kata Kunci: beauty vlogger, endorsement, minat beli 


\section{Pendahuluan}

Peningkatan pengguna internet merupakan potensi pasar yang besar bagi para pelaku bisnis untuk memperluas pangsa pasar serta guna meningkatkan penjualan. Hal ini dikarenakan, internet merupakan salah satu sarana komunikasi pemasaran yang efektif bagi para pelaku bisnis untuk meningkatkan penjualan produknya. Sarana yang paling tepat adalah melalui media promosi iklan. Iklan merupakan suatu proses komunikasi serta promosi yang bertujuan untuk membujuk atau mengajak orang untuk mengambil tindakan yang menguntungkan bagi pihak perusahaan seperti memutuskan untuk membeli. Iklan sendiri selain menyediakan informasi mengenai produk juga berfungsi untuk mempersuasi calon pembeli atas produk yang ditawarkan.

Dengan Instagram perusahaan dapat menawarkan produknya melalui beauty vlogger dan endorsement guna meningkatkan minat beli produk kosmetik yang ditawarkan. Rumusan pokok masalah yang akan dibahas dalam penelitian ini adalah sebagai berikut: Apakah terdapat Pengaruh Endorsement oleh Beauty Vlogger terhadap Minat Beli Kosmetik Follower Instagram @Storyofsand ? dengan hipotesis penelitian $\mathrm{H}_{0}$ yaitu tidak terdapat pengaruh endorsement oleh beauty vlogger terhadap minat beli kosmetik follower Instagram @Storyofsand. Sedangkan Ha yaitu terdapat pengaruh endorsement oleh beauty vlogger terhadap minat beli kosmetik followerInstagram@Storyofsand.

\section{Teori Komunikasi Pemasaran}

Menurut Four as (the American of Advertising Agency), Integrated Marketing Communication (IMC) atau Komunikasi Pemasaran Terintegrasi adalah konsep perencanaan komunikasi pemasaran yang mengakui nilai tambah dari perencanaan komprehensif yang mengkaji peran strategi masing-masing bentuk komunikasi misalnya iklan, respon langsung, promosi penjualan, dan humas (hubungan masyarakat) serta memadukannya untuk meraih kejelasan pesan, konsistensi, dan dampak komunikasi maksimal melalui terintegrasi pesan. Secara singkat IMC berarti menyatukan perencanaan, tindakan dan koordinasi pada semua wilayah komunikasi pemasaran dan juga memahami konsumen menyangkut apa sesungguhnya tanggapan konsumen (Hermawan, 2012: 51).

\section{Beauty Vlogger}

Menurut Maria dan Kusumawati (2018:188) vlogger adalah pembuat video blog yang berisikan materi post berupa video. Jenis video ini biasanya menampilkan rekaman profil seseorang, aktivitas sehari-hari yang dilakukan oleh orang tersebut, serta pengalaman-pengalaman yang dirasakan dan sebagainya. Terdapat beberapa macam jenis vlogger yang saat ini berkembang, salah satunya adalah beauty vlogger.

Menurut Puspita dan Mawardi (2017:64), beauty vlogger merupakan seseorang atau kelompok yang membuat $v \log$ bertujuan untuk merekomedasikan dan mengulas tentang kecantikan serta produk yang digunakan. Sejalan dengan definisi di atas Putri dan Junaidi (2018:282), menjelaskan beauty vlogger merupakan sebutan untuk para pembuat konten berupa video yang fokus pada dunia kecantikan, dimana $v \log$ merupakan bentuk publikasi online yang memungkinkan semua orang terhubung dengan akses web dan peralatan video sederhana seperti telepon genggam dan komputer merupakan kegiatan personal pada Youtube. 


\section{Instagram}

Menurut Puspita (2017:5), media sosial adalah medium di internet yang memungkinkan pengguna merepresentasikan dirinya maupun berinteraksi, bekerja sama, berbagi, berkomunikasi dengan pengguna lain, dan membentuk ikatan sosial secara virtual. Sedangkan Adinda dan Pangestutu (2019) menjelaskan Instagram merupakan sebuah aplikasi dari smartphone khusus untuk media sosial yang merupakan salah satu dari media digital yang mempunyai fungsi hampir sama dengan twitter, namun perbedaannya terletak pada pengambilan foto dalam bentuk atau tempat untuk berbagi informasi terhadap pengguna nya

\section{Endorsement}

Menurut Tobin (dalam Maria dan Kusumawati 2018:190), endorsement merupakan segala bentuk pesan yang diberikan dalam kegiatan pemasaran, di mana konsumen cenderung mempercayai opini, keyakinan, pendapat, atau pengalaman dari pihak lain selain perusahaan tersebut sebagai sponsor. Endorser adalah ikon atau sering disebut juga sebagai sumber langsung untuk mengantarkan sebuah pesan dan atau memperagakan sebuah produk atau jasa dalam kegiatan promosi yang bertujuan untuk mendukung efektifitas penyampaian pesan produk (Belch dan Belch, 2004:168).

Menurut Shimp (2011:460), celebrity endorser adalah iklan yang menggunakan orang atau tokoh terkenal dalam mendukung suatu iklan. Jadi celebrity endorser merupakan sebuah promosi yang dilakukan oleh perusahaan dengan mengeluarkan produk melalui media iklan dan menggunakan seorang selebriti sebagai pendukung iklan tersebut. Lebih lanjut Shimp (2011:251-253) menyatakan bahwa alat ukur yang dapat digunakan mengukur keberhasilan endorsement dengan menggunakan indikator :

1) Trustworthiness (Dapat dipercaya)

2) Expertise (Keahlian)

3) Attractiveness (Daya Tarik)

4) Respect (Kualitas dihargai)

5) Similarty (Kesamaan)

\section{Minat Beli}

Kotler dan Keller (2009:137) menyatakan bahwa minat beli berarti munculnya perilaku konsumen sebagai respon terhadap suatu objek dengan menunjukkan rasa ingin untuk membeli. Minat beli adalah suatu model dimana sikap seseorang sangat cocok dengan objek dalam mengukur sikap terhadap kategori produk, jasa serta brand tertentu (Schiffman dan Kanuk, 2010:228). Sedangkan Simamora (2011:106) menjelaskan minat beli terhadap suatu produk timbul karena adanya dasar kepercayaan terhadap produk yang diiringi dengan kemampuan untuk membeli produk. Lebih lanjut Schiffman dan Kanuk (dalam Anggraeni et.al. 2018: 158) menyebutkan 5 indikator dalam mengukur minat beli, sebagai berikut :

1) Memiliki keinginan untuk mencari informasi tentang produk

2) Melakukan pertimbangan untuk membeli

3) Memiliki keinginan untuk mencoba

4) Memiliki rasa ingin tahu terhadap produk

5) Ingin memiliki produk. 


\section{Metode Penelitian}

Penelitian ini merupakan penelitian untuk mengukur pengaruh Endorsement dalam Beauty Vlogger terhadap minat beli kosmetik, dengan menggunakan pendekatan kuantitatif. Sugiyono (2018:15) diartikan sebagai penelitian berlandaskan pada filsafat positivism, digunakan untuk meneliti pada populasi atau sampel tertentu, pengumpulan data menggunakan instrumen penelitian, analisis data bersifat kuantitatif atau statistik, dengan tujuan untuk menggambarkan dan menguji hipotesis yang telah dibuat. Penelitian ini menggunakan metode deskriptif dan verifikasi dan menggunakan suatu perhitungan melalui metode statistic dengan menggunakan software SPSS 25.0.

Populasi menurut Sugiyono (2018: 130) yaitu wilayah generalisasi yang terdiri atas obyek/subyek yang mempunyai kualitas dan karakteristik tertentu yang ditetapkan oleh peneliti untuk dipelajari dan kemudian ditarik kesimpulannya. Maka Populasi dalam penelitian ini adalah followers Instagram @Storyofsand berjumlah 6.988 followers, dengan data berdasarkan akun@Storyofsand. Dari populasi tersebut peneliti mengambil sampel yang untuk mewakili penelitian dengan menggunakan teknik pengambilan sampel purposive sampling. Menurut Sugiyono (2018: 138) purposive sampling yaitu teknik penentuan sampel dengan pertimbangan tertentu.

Karakteristik sampel dalam penelitian ini adalah pengguna Instagram yang menjadi followers@Storyofsand dan diambil menggunakan rumus Slovin (Umar, 2008:78) untuk menentukan jumlah banyak sampel yang akan digunakan dalam penelitian ini dengan persentase kelonggaran ketidaktelitian adalah sebesar 10\% diperoleh sampel sebesar 100 sampel.

Menurut Sugiyono (2017:276) yang dimaksud teknik analisis data adalah kegiatan setelah data dari seluruh responden atau sumber data lain terkumpul. Teknik analisis data yang akan peneliti gunakan dalam penelitian ini adalah sebagai berikut:

1) Uji Validitas

2) Uji Reliabilitas

3) Uji Hipotesis

4) Koefisien Determinasi R Square

5) Analisis Regresi Linear Sederhana

\section{Hasil Temuan dan Diskusi}

\section{Hasil Uji Validitas}

Hasil pengujian validitas terhadap variabel endorserment (X) dapat dilihat bahwa nilai $r$ hitung dari masing-masing indikator pertanyaan lebih besar dari $r$ tabel 0.16 dengan nilai $\mathrm{r}$ hitung terkecil 0.182 . Dapat disimpulkan bahwa pernyataanpernyataan pada kuesioner adalah valid atau layak dalam mendefinisikanvariabel endorserment $(\mathrm{X})$ begitupula dengan pengujian validitas terhadap variabel minat beli (Y) nilai nilai $r$ hitung dari masing-masing indikator pertanyaan lebih besar dari $r$ tabel 0.16 dengan nilai $\mathrm{r}$ hitung terkecil 0.535 . Dapat disimpulkan bahwa pernyataanpernyataan pada kuesioner adalah valid atau layak dalam mendefinisikan variabel minat beli (Y). 
Tabel 1. Hasil Uji Reliabilitas

\begin{tabular}{lccc}
\hline Variabel & Cronbach's Alpha & r tabel & Ket. \\
\hline Endorserment & 0.790 & 0.7 & Reliabel \\
Minat Beli & 0.934 & 0.7 & Reliabel \\
\hline
\end{tabular}

Sumber: Dokumentasi Peneliti

Dari data Tabel diatas menunjukkan bahwa nilai Cronbach `s Alpha untuk masing-masing variabel diatas ketentuan nilai yang disyaratkan $(>0,7)$. Maka dikatakan bahwa konstruk pernyataan yang merupakan variabel endorserment (X) menunjukkan $0.790>0.7$ dengan interpretasi kriteria sedang, minat beli (Y) menunjukkan $0.934>0.7$ dengan interpretasi kriteria sangat tinggi dinyatakan reliable.

Tabel 2. Hasil Uji Determinasi

\begin{tabular}{lcc}
\hline Model & R & R Square \\
\hline 1 &, $791^{\mathrm{a}}$ &, 625 \\
\hline \multicolumn{2}{l}{ Sumber: } & Dokumentasi Peneliti
\end{tabular}

Terdapat pengaruh endorsement $(\mathrm{X})$ terhadap minat beli $(\mathrm{Y})$ dalam pengaruh endorsement dalam beauty vlogger terhadap minat beli kosmetik "studi kasus followers Instagram@storyofsand pada sebesar 0.625 (62,5\%) dan sisanya 37,5\% dipengaruhi faktor lain diluar variabel penelitian ini.

Tabel 3. Hasil Uji Hipotesa

\begin{tabular}{lcc}
\hline Model & $\mathrm{t}$ & sig \\
\hline contanta & $2,065^{\mathrm{a}}$ &, 042 \\
Endorsement & 12,790 &, 000 \\
\hline
\end{tabular}

Sumber: Dokumentasi Peneliti

Dari penelitian yang telah dilakukan diperoleh hasil bahwa endorsement (X) mempunyai pengaruh yang signifikan terhadap minat beli dengan nilai signifikansi sebesar $0.000<0.10$ maka sesuai dengan dasar pengambilan keputusan yang dibuat maka dapat disimpulkan endorsement $(\mathrm{X})$ berpengaruh terhadap minat beli $(\mathrm{Y})$, sedangkan pengaruh yang ditimbulkan adalah positif artinya semakin followers melihat tutorial makeup @storyofsand dapat meningkatkan minat beli terhadap produk kosmetik.

\section{Pembahasan Hasil Penelitian}

Dari hasil penelitian dapat ditunjukkan dengan nilai signifikansi sebesar 0,000 $<0,10$ dapat disimpulkan bahwa endorsement berpengaruh signifikan dan positif terhadap minat beli. Hal ini terjadi karena endorsement dalam beauty vlogger merupakan salah satu faktor yang mempengaruhi minat beli konsumen dalam hal ini followers@storyofsand. Berdasarkan dari jawaban rumusan masalah yang ada bahwa 
terdapat pengaruh antara variabel endorsement dengan variabel minat beli konsumen. Dapat di lihat hasil penelitian berupa determinasi r square bahwa endorsement dapat mempengaruhi minat beli followers dalam akun Instagram@storyofsand sebesar $66,5 \%$. Hasil penelitian ini sama seperti hasil penelitian terdahulu peneliti dari Anggraeni et.al (2018) dimana endorsement beauty vlogger (X) berpengaruh terhadap minat beli (Y). Hal ini ditunjukkan dengan nilai probabilitas $\mathrm{t}(0,000)<\alpha=0,05$. Dengan koefisien determinasi (R2) atau ketepatan model yang didapatkan sebesar $24,2 \%$ artinya bahwa ketepatan model dari variabel endorsement beauty vlogger (X) dan Minat Beli (Y) sebesar 24,2\%. Begitu pula dengan penelitian Prabowo(2014) dan Mariyanti dengan terdapat nya pengaruh positif dan signifikan antara variabel endorsement $(\mathrm{X})$ dengan variabel minat beli $(\mathrm{Y})$. Dikarenakan endorsement dalam beauty vlogger merupakan orang yang memiliki banyak followers dimana mereka dipandang sebagai contoh yang dipandang memiliki daya tarik (attractiveness), kredibilitas (credibility), keahlian (expertise) dan layak dipercaya (trust worthiness).

Menurut Kinnear dan Taylor (1995) dalam Nela Kristiana (2012), minat beli adalah tahap kecenderungan responden untuk bertindak sebelum keputusan membeli benar-benar dilaksanakan. Sejalan dengan hal tersebut hasil penelitian ini sama seperti hasil penelitian yang dilakukan Yusan Gamaro Pontoh (2016) yang menyatakan minat membeli merupakan sebuah pengambilan keputusan untuk membeli suatu merek diantara berbagai merek lainnya. Adapun minat membeli itu muncul melalui berbagai rangkaian proses, antara lain yaitu pengenalan kebutuhan, pencarian informasi, evaluasi informasi dan akhirnya akan timbul sebuah minat beli yang ada pada diri konsumen. Minat beli yang tinggi mencerminkan tingkat kepuasan konsumen ketika memutuskan untuk mengadopsi suatu produk.

\section{Simpulan}

Variabel independen endorsement berpengaruh positif dan signifikan terhadap minat beli produk kosmetik oleh followers Instagram@Storyofsand. Pengaruh endorsement sebagai variabel x memiliki pengaruh sebesar 0.675 atau $67.5 \%$ terhadap minat beli produk kosmetik oleh followers Instagram @Storyofsand dan sisanya $32.5 \%$ dipengaruhi faktor lainnya di luar penelitian.

\section{Ucapan Terima kasih}

Pertama-tama penulis mengucapkan terima kasih kepada Tuhan Yang Maha Esa atas semua berkat dan kemudahan yang telah diberikan-Nya untuk penulis hingga terselesaikannya penelitian ini, kepada kedua orang tua penulis yang senantiasa mendukung baik secara material dan spiritual. Ucapan terimakasih penulis persembahkan kepada Alexander Sandy Watt pemilik akun@storyofsand yang telah menjadi obyek penelitian oleh penulis serta bantuannya mendukung dan memfasilitasi penyebaran kuesioner melalui akun@storyofsand.

\section{Daftar Pustaka}

A Shimp, Terence. (2011). Periklanan Promosi (Aspek Tambahan Komunikasi Pemasaran Terpadu). Jilid I, edisi Terjemahan, Jakarta: Erlangga.

Anggraeni et.al. (2018). Pengaruh Endorsement Beauty Vlogger terhadap Minat Beli Make Up Brand Lokal "Survey Pada Peminat Kosmetik 1t Pro yang dipengaruhi 
oleh Video Vlog Ini Vindy di Kota Malang. Jurnal JAB, 60 (2), 155-162

http://administrasibisnis.studentjournal.ub.ac.id/index.php/jab/article/view/2492/288 $\underline{3}$

Belch, G.E and M.A. Belch. (2004). Advertising And Promotion: An Integrated Marketing Commnunications Perspective, Sixth Edition, The McGraw Hill/Irwin: New York.

Bilson, Simamora. (2011). Memenangkan Pasar dengan Pemasaran Efektif dan Profitabel. Jakarta: PT. Gramedia Pustaka Utama

Durianto, Darmadi (2013). Strategi Menaklukan Pasar Melalui Riset Ekuitas dan Perilaku Merek (cet. ke-10). Jakarta: PT Gramedia Pustaka Utama

Ghozali. (2016). Aplikasi Analisis Multivariete Dengan Program IBM SPSS. Semarang: Badan Penerbit Universitas Diponegoro.

Husein, Umar. (2008). Metode Penelitian Untuk Skripsi dan Tesis Bisnis. Jakarta. PT Rajagrafindo Persada

Kotler, Philip., \& Keller, Kevin, L. (2013). Manajemen Pemasaran, Jilid Kedua, Jakarta: Erlangga.

Luh, D. M. (2017). Pengaruh Celebrity Endosers dan Pesan Iklan di Televisi Terhadap Keputusan Pembelian Pada Es Krim Walls Magnum Belgium Chocolate. Jurnal Prologia, 3 https://journal.untar.ac.id/index.php/prologia/article/viewFile/6247/4351

Maria, R. E. S., \& Kusumawati, A. (2018). Pengaruh Youtube Beauty Vlogger Terhadap Minat Beli Konsumen Dan Dampaknya Terhadap Keputusan Pembelian Produk (Studi pada Pengguna Kosmetik Maybelline di Indonesia). $\begin{array}{llll}\text { Jurnal } & J A B, & 63 & \text { (1), }\end{array}$ http://administrasibisnis.studentjournal.ub.ac.id/index.php/jab/article/view/271 $\underline{5 / 3110}$

Mariyanti. (2017). Pengaruh Celebrity Endosers dan Pesan Iklan di Televisi Terhadap Keputusan Pembelian Pada Es Krim Walls Magnum Belgium Chocolate. EJurnal Manajemen Unud, 4 (10), 3093-3118 https://ojs.unud.ac.id/index.php/Manajemen/article/view/14429/10522

Prabowo et.al. (2014). Pengaruh Celebrity Endorser Terhadap Minat Beli (Survei pada Pengunjung 3Second Store di Jalan Soekarno Hatta Malang). Jurnal $J A B, 14$ http://administrasibisnis.studentjournal.ub.ac.id/index.php/jab/article/view/594

Puspita, W. D., \& Mawardi, M. K. (2017). Pengaruh Beauty Vlogger Terhadap Source Characteristics Serta Dampaknya Terhadap Purchase Intention. Jurnal JAB, 47(1), http://administrasibisnis.studentjournal.ub.ac.id/index.php/jab/article/view/181 $\underline{7}$

Schiffman, L.G., \& Kanuk, L.L. (2010). Consumer Behaviour (10th ed). New Jersey, Pearson Prentice Hall.

Sugiyono. (2018). Metode Penelitian Kuantitatif, Kualitatif, dan R\&D. Bandung: Alfabeta 